\title{
Perspectives on E-books from Instructors and Students in the Social Sciences
}

\section{Amy Hoseth and \\ Merinda McLure}

Amy Hoseth is a College Liaison Librarian and Merinda McLure is the Applied Human Sciences Librarian at Colorado State University Libraries, Fort Collins, Colorado. Submitted for review May 18, 2011; revised and accepted for publication August 19, 2011.

Reference \& User Services Quarterly, vol. 51, no. 3, pp. 278-88

(c) 2012 American Library Association. All rights reserved.

Permission granted to reproduce for nonprofit, educational use.
To explore attitudes toward e-books, the authors conducted focus groups at Colorado State University with instructors (7) and graduate students (12) from four social science disciplines. Participants provided insights into their use of print and electronic texts, their attitudes toward patron-driven e-book purchasing, potential barriers to e-book use and acceptance, and how they view the academic library within the context of their own research needs. The paper includes a review of relevant literature and use studies. It will be useful to academic librarians and administrators concerned with patron-driven and e-book purchasing.

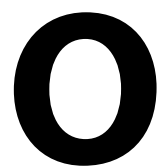
ver the past several decades the Colorado State University (CSU) Libraries have gradually provided the campus community with increased access to e-books: as of March 2011, more than 135,000 titles were available on a variety of vendor platforms. Most recently, the Libraries have focused additional attention on implementing a patron-driven purchasing model for the acquisition of e-books, endorsed by the recommendations of a 2009 CSU Library-Information Technology Task Force and influenced by the successes of patron-driven e-book purchasing projects pursued at institutions such as the University of Texas and the University of Denver. With this increased attention to and investment in patrondriven e-book purchasing, the authors wished to explore the attitudes and perceptions of students and instructors at CSU concerning e-books, their thoughts on the potential benefits and limitations of patron-driven purchasing, and more broadly, their perspectives on the role of library resources in their scholarly activities.

The CSU Libraries' patron-driven purchasing program is a work in progress and accounts for a portion of the Libraries' total e-book purchasing. The program is facilitated through the ongoing addition of Ebook Library (EBL) records to the library catalog, according to criteria established via an EBL profile. In the first phase of the Libraries' experimentation with patron-driven purchasing, only EBL records for those titles published by Wiley, Routledge, and CABI have been added to the catalog. Additional selection criteria exclude titles published in languages other than English; titles falling in the EBL subject categories of religion, law, library science, military science, museums, or nursing; titles published before 2009; and titles with a price exceeding $\$ 300$. $^{1}$

Since the program's launch in spring 2010, the number of EBL e-book 
records in the catalog has grown from 4,745 in early May 2010 to 9,517 in March 2011. Patrons discover EBL titles of interest via the catalog and gain seamless, short-term access to the full text after first authenticating as CSU affiliates via Shibboleth. Following an initial five-minute access period, the EBL interface asks the user if he or she wishes to initiate a short-term loan. Four 24-hour short-term loans of a title trigger a purchase by the Libraries (which includes 325 nonlinear uses per year, renewed annually at no additional cost) while users experience uninterrupted access.

In an era of shrinking economic resources, patron-driven purchasing represents one way to focus monograph expenditures on those titles specifically desired by users. The electronic format of e-books makes them broadly accessible to users, regardless of physical location, while simultaneously circumventing the space crunch that is common in the modern academic library. Today's e-book platforms generally offer improved functionality (including note-taking, embedded hyperlinks, refined searchability, and more) when compared to the static, Portable Document Format (PDF) typical of early e-books.

\section{LITERATURE REVIEW}

As the use and availability of e-books increase, a growing amount of scholarly research is exploring how users interact with these digital resources. In addition, a number of major national studies, including the JISC National e-Book Observatory project in the UK, are beginning to bear fruit in the form of published articles reporting multiple aspects of e-book research. For this study the researchers reviewed articles published between 2004 and 2010 that were related to e-book use in higher education. Particular attention was given to research that reported student and faculty preferences.

\section{E-Book Challenges and Developments}

Scholarly e-books have been available since the late 1990s, yet they still present significant challenges for libraries. ${ }^{2}$ Connaway and Wicht reviewed literature about e-books that was published between 2000 and 2007 and noted that,

several themes consistently appear in the literature on the barriers to the adoption and integration of e-books into library collections, services, and systems. These include the lack of e-book and hardware standards; incompatible rights and operability; unrealistic price, purchase, and access models; and limited discovery and delivery options. ${ }^{3}$

Rafael Ball notes that persistent challenges for libraries include complex e-book business models and varied use and licensing conditions. ${ }^{4}$ E-books also present challenges for users and librarians: navigation, printing, and note-taking functions may work differently on each e-book platform, ${ }^{5}$ for example, and "the lack of interoperability of e-book hardware requires libraries to support e-books on different hardware platforms-not just workstations or laptops, but also dedicated readers, PDAs, and mobile phones."

Although there is a great deal of librarian interest in patron-driven purchasing models for acquiring e-books, relatively few articles on this topic have been published to date. Levine-Clark reported on plans to pursue this model, in hopes that "the University of Denver's transition to demanddriven acquisition of scholarly monographs will allow purchase of a better selection of books for its users than it has in the past." A recent pilot project between the University of York and Springer-Verlag to "evaluate the potential of a user-driven purchasing model" allowed York to assess several variables, including a review of the most-used Springer-Verlag e-book titles and a cost analysis of user-driven purchasing versus the outright purchase of e-book collections. ${ }^{8}$ Hodges, Preston, and Hamilton report on Ohio State University Libraries' efforts to study their patron-driven purchasing activities, describing common issues with this acquisitions model, such as profiling for appropriate title selection and the difficulty of predicting patron use (and, hence, actual purchasing costs). ${ }^{9}$ The continued development and study of patrondriven purchasing should prove interesting, given that the wider implementation and success of this approach appears to be directly tied to business models that allow libraries to control costs and to increase and diversify title availability. As Hodges, Preston, and Hamilton note, currently "even the largest e-book aggregators have rights to distribute only a fraction of the titles published each year in the United States." ${ }^{10}$

\section{USE STUDIES}

Today an expanding body of use studies report on student and faculty responses to, and interactions with, e-books. While these studies vary in terms of population and the specific methodologies employed, they demonstrate many common user reactions and behaviors that appear to be related to the current state of e-book functionality and availability. It seems plausible to suggest that user concerns may become more specific or differentiated as e-books grow more sophisticated, and as the universe of available scholarly e-books grows larger and more diverse.

\section{Format Preference: Print versus Electronic}

Perhaps because libraries are now maintaining blended collections of both print and e-books and are increasingly able to choose one format over the other when purchasing a given title, many studies have explored users' format preferences.

In a 2007 study, Southwest Baptist University surveyed students, faculty, and staff about their preference for reading print versus e-books in relation to research, textbooks, and leisure reading. Survey results indicated that all users "overwhelmingly indicated a preference for using print books 


\section{FEATURE}

rather than e-books for all three tasks." ${ }^{11}$ A 2009 SpringerVerlag study of end users and librarians in Greece, Turkey, and Germany was optimistic about the future of e-books for scholarly research, although results indicated that "students and researchers perceive reading from the computer or PDA screen as difficult ... and print books are still preferred for cover to cover reading." ${ }^{" 12}$ These articles support earlier research by authors including Langston, ${ }^{13}$ which indicated a user preference for print books when users were given a choice between print and electronic. Individuals may report preferring print for reasons such as format familiarity, the tactile characteristics of print books, or a preference for reading in a variety of locations, untethered from an electronic device.

Nonetheless, findings do vary. Croft and Davis report that in both the 2003 and 2009 iterations of their survey, just over half of "student respondents ... said 'no' to preferring a print version of the book over the e-book version." ${ }^{14}$ Jamali, Nicholas, and Rowlands report that "users found different and supplementary applications for e-books and hard copy and wanted to benefit from both. Students do not want to see an exclusivity of formats." ${ }^{15}$ While it appears that users most often report feeling that the intellectual process of reading and absorbing a book is better supported by the print format, Gregory found that "students who indicated a preference for e-books also reported that their reading comprehension was better from a computer screen."16

\section{Positively Regarded Aspects of E-books}

A number of positively regarded e-book characteristics and features emerge repeatedly in use studies. The ready availability and accessibility of e-books is frequently noted, ${ }^{17}$ and users observe that whereas print copies constrain access to a limited number of simultaneous users, e-book access may be instantaneously available to multiple, concurrent readers. In Croft and Davis' 2009 study, "the feature rated very important more times than any other was 'any-time access."'18

Convenience is another often-mentioned benefit of electronic books, ${ }^{19}$ as e-books may be accessed at a distance and downloaded to a personal device. The convenience of online access was one of the top two advantages of e-books identified by respondents to the open-ended questions included in the JISC observatory project's survey. ${ }^{20}$ Additional e-book aspects frequently and positively related to convenience include: portability, ${ }^{21}$ cost savings due to users' perception that e-book availability may decrease the total number of books they need to buy, ${ }^{22}$ content currency at least partly due to users' assumption that e-books may be more current, ${ }^{23}$ and efficiency and ease of navigation within e-books. ${ }^{24}$

The ease with which users can search within e-books is another frequently mentioned benefit. ${ }^{25}$ The convenience of searchability was "the second most mentioned [advantageous] characteristic" of e-books identified by respondents to the JISC observatory project's survey, ${ }^{26}$ and searchability was one of the most highly rated e-book features in Croft and Davis' 2009 study. ${ }^{27}$
The ability to print and copy from e-books is often highlighted by users. ${ }^{28}$ Students may appreciate that they can selectively print the e-book content they need or want. ${ }^{29}$ Interestingly, Levine-Clark's 2006 study found that users' tendency to print e-book content varied according to factors such as the extent of text to be read, "the need to come back to material at a later time and the desire to annotate or highlight the text [offline]." 30 The ability to copy and paste selections of text is frequently perceived as an advantage of e-books.

Finally, users seem to perceive e-books as more environmentally friendly than print, ${ }^{31}$ and, interestingly, some users perceive that e-books may assist libraries' perpetual space concerns. $^{32}$

\section{Negative Perceptions of E-books}

Concerns about reading online are among the most frequently mentioned negative perceptions of e-books that have appeared in the research..$^{33}$ Users may perceive that they experience eyestrain, and this may be cited as a factor in users' selective-rather than start-to-finish-reading of e-book content. ${ }^{34}$ Others may simply find reading online to be uncomfortable or undesirable. Users have also indicated that they want to be able to download e-books and work offline, rather than being tethered to the Internet, either because of individual preference or the need to use e-books in situations where Internet access is not available..$^{35}$ The ability to download an e-book for offline use was one of the most frequently rated features by participants in Croft and Davis' 2009 study. ${ }^{36}$

Several other noteworthy trends are visible across e-book use studies. Users appear to read selectively. ${ }^{37}$ As Hernon et al. note, "except for the literature majors reading e-novels, the participants do not want to spend much time with a digital book. If they have to, they print the relevant portions to read." ${ }^{38}$ In Levine-Clark's study, only 7.1 percent of more than 1,100 respondents who were e-book readers indicated that their typical e-book use behavior was to a read a title in its entirety. ${ }^{39}$ Similarly, in the JISC study, Nicholas et al. found that most users "seem to dip in and out of e-books rather than reading them sequentially."40

Several studies suggest that users appear to seek e-books for specific purposes, "such as research, reference, and homework." ${ }^{11}$ Noorhidawati and Gibbs' study categorized e-book use into three main purposes (fact finding, finding relevant content, and extended reading), and found that students most often used e-books to find relevant content in support of research and projects. ${ }^{42}$

\section{Disciplinary Differences}

A number of studies have considered faculty, researcher, and student e-book use and attitudes within specific disciplines. Rowlands et al. found that "attitudes towards e-books, print titles, and libraries vary, sometimes considerably so, by age, academic status, and (especially) by subject." ${ }^{33}$ Generally 
speaking, however, these studies tend to reveal few significant disciplinary differences. These distinctions may become more pronounced as both this body of research and the sophistication of use studies evolve.

Anuradha and Usha's frequently cited article reports their survey of student and staff researchers at the Indian Institute of Science. ${ }^{44}$ All but 10 percent of respondents were somewhat satisfied or satisfied with their e-book use and none of the findings stand out as specific to the science or technology orientation of this study's participants. ${ }^{45}$

Bierman, Ortega, and Rupp-Serrano surveyed and interviewed ten science and engineering faculty at the University of Oklahoma; the results "did not provide marked differences in e-book usage between faculty in applied sciences and faculty in pure sciences." ${ }^{146}$ These different populations did, however, express a few specific desires: "pure sciences faculty expressed interest in the ability to manipulate graphics, while applied sciences faculty indicated interest in the ability to copy programs." ${ }^{47}$ Foote and Rupp-Serrano report another e-book use study at the University of Oklahoma, this time conducted with nine faculty and nine graduate students in the geosciences who completed a survey and were then observed interacting with e-books. ${ }^{48}$ This study revealed several user concerns and preferences that seem to speak to the participants' disciplinary affiliation: "high-quality graphics are essential to the discipline"49 and the unavailability of electricity when conducting fieldwork may be a "deterrent to using e-books," necessitating the option to download and use e-books offline..$^{50}$ Nariani also explored e-book use in the sciences, although the findings were limited to information about e-book features, accessibility, and promotional methods. $^{51}$

Levine-Clark explored e-book use in the humanities. ${ }^{52}$ While he found that "humanists (and social scientists) have a higher degree of awareness about electronic books than the rest of the university community," given their heavy reliance on the library catalog as part of their research process, this awareness did not translate to greater e-book use. ${ }^{53}$

Finally, Nicholas, Rowlands, and Jamali examined e-book use among business and management students as part of the JISC National e-Book Observatory study, finding that "business students are major and significant users of e-books and e-textbooks and that they view them more frequently, spend longer viewing them, [and] view more of them." ${ }^{54}$ This popularity, they noted, could be attributed to a number of factors, including the possibility that there are more business and management students, and "the nature of business studies means that e-books are especially attractive." ${ }^{\prime 55}$

\section{METHOD}

Between September and November 2010, the researchers conducted a series of 6 focus groups with participants from selected social sciences disciplines with prior approval from the university's institutional review board (IRB).
To recruit participants, the researchers sent e-mail invitations to faculty/instructors and graduate students in the departments of Education, Psychology, Human Development and Family Studies, and Social Work. The authors serve as the liaison librarians for these departments and their professional interest in affiliated students and faculty served as the basis for this targeted recruitment. Only faculty and graduate students were recruited for participation, as the authors felt that these populations were likely to be most invested in the Libraries' increasing acquisition of e-books and adoption of patron-driven purchasing. Participants were self-selecting and may have had a greater interest in the Libraries than their peers and colleagues, as well as an interest in supporting the research efforts of the authors. Interested individuals registered for the focus groups by completing a brief online registration form.

A total of 19 individuals ultimately participated in the focus groups; 12 graduate students and 7 faculty. Prior experience with e-books was not a prerequisite for participation in the study, however 1 focus group question specifically addressed prior e-book use; responses indicated that 5 of the 7 faculty participants and 10 of the 12 graduate student participants had previously used an e-book. The authors acknowledge that the focused recruitment of participants, their self-selection, and the small sample size all potentially limit the direct transferability of the study findings.

Separate focus groups were held for each user group: 3 for faculty, and 3 for graduate students. All participants received lunch during the 90-minute focus groups, which were conducted over the noon hour. Participants were asked a series of questions (appendix) focused in three main areas:

- Their use of and familiarity with e-books, both from the CSU Libraries and in general

- Their attitudes toward patron-driven e-book purchasing

- Their interactions with the CSU Libraries (both physically and virtually) and the role that the library and its collections play in their scholarly research.

Each focus group was recorded using a digital audio recorder and the resulting recordings were transcribed by a third-party vendor. The research team used a method outlined by Krueger and Casey to analyze the focus group comments. ${ }^{56}$

\section{FINDINGS}

Both unique perspectives and clear themes emerged from the responses of focus group participants and are common outcomes of focus group discussions. Unique responses inform our understanding of individual variations in preferences, scholarly behaviors and habits, and interactions with e-books. In contrast, repeated themes identify shared perspectives and common experiences. Among the notable themes that emerged from this research were: 


\section{FEATURE}

- Specific positive perceptions and concerns related to ebooks

- A preference for print in certain situations

- Reflections on the intellectual process as it relates to print and e-books

- Awareness of the need to adapt to change

- Expectations and concerns regarding patron-driven purchasing models and purchasing behavior, and

- Insights into how users discover print and e-books and how they prefer to receive information about e-books.

\section{Positive Perceptions of E-books}

In reviewing the participants' comments, several prominent themes emerged about the perceived benefits of e-books. Both students and faculty addressed the seismic shift that has taken place in relation to e-resources and discussed how it has affected their research and library habits. As one faculty member commented,

If I go to the library, I'm here for a couple of hours. I don't run over for 15 minutes. It's a visit. I plan to have coffee, I plan to roam the stacks ... [yet] I think I would use an e-book because I could search it. It would be faster. And I could do it from my laptop, which would be eminently wonderful. And I've already made that adaptation. I love the electronic resources. I don't know how I would've done my dissertation work without that. It's just amazing to me to have watched that transition to electronic journal articles. I mean, that has changed my life.

Many respondents commented on the ease with which users can search within e-book texts to find specific information. This ability to easily and comprehensively search across an e-book's entire text is effectively lacking in print books. One respondent noted that this ability would be particularly useful in his genealogy research, where he often must comb through many pages to find a particular name or date. Another element of e-book use that generated positive comments was the idea of quick, easy access and convenience. Responses indicate that this "instant access" is particularly helpful for those who live off campus, distance students, and those juggling work, school, and family life who may not find it convenient to visit the library in person. One individual commented that e-books would be ideal for suggested course readings, when multiple students might require access to a single text.

Several faculty members commented on potential publication-related advantages of e-books. One wondered whether e-books may be more instantly available (and current) due to a potentially shorter turnaround time between authorship and publication. Another noted that many academic books focus on very specific topics, and while they are unlikely to generate significant revenue they are still important to the scholarship of their niche audience. With that in mind, the faculty member wondered whether e-books might provide a cost-effective option for the publication of items that might be very narrow in scope, in contrast to print books which often "cast a wide net."

Other e-books benefits mentioned by participants included portability, space-saving potential, the ease with which e-books enable users to read specific sections of a book, and the simplicity of cutting-and-pasting.

\section{CONCERNS RELATED TO E-BOOKS}

Both students and faculty identified a number of concerns that they associate with e-books and e-book use. The most commonly mentioned concern was the perceived inability to write in e-books or flag pages for future reference. Other expressed concerns related to the presentation of e-books included restrictions on the number of pages that can be printed from an e-book, an inability on some platforms to easily cut-and-paste text from e-books, and an inability to flip easily between multiple e-books at one time, as is possible when working with print texts. As one student commented,

I want to be able to have several documents open at the same time and compare, and that is the one limitation with e-books or even electronic articles. I often print them, because I want to flip to different parts. So I want to be able to do [keyword searching] . . . and then I additionally want to be able to have several [books] open at the same time and physically be able to see them at the same time.

Several respondents expressed concern about the limited check-out (or download) period for e-books, particularly in comparison to print books. Noted one student,

I really find that the one-week checkout is not sufficient. If we're graduate students and are given books for six months physically, why can't we be given access to an electronic book for at least 30 days? And actually that's been a detraction for me, when I have checked out an e-book and wanted it as a referential tool, to think that well, it's sitting there in the reader, but 14 days from now I'm going to have to go through the hoops of checking it back out.

A number of students and faculty expressed a strong desire for e-books to permit simultaneous access by multiple individuals. Several individuals also expressed concerns related to accessibility-specifically, that e-books might not be accessible to all individuals equally, particularly those with limited financial means or college students who do not own their own computers. Another commonly expressed theme was concern about e-book formats and how e-books may appear on different devices (such as smart phones, e-readers, and computers). Several respondents commented that e-books do not always 
work the same way, if at all, on different devices, and that this lack of a common e-book format and functionality can be confusing and frustrating.

Other identified concerns with e-books included questions about the affordability of e-books; eye fatigue and headaches from viewing resources online; a desire to read longer documents, such as dissertations, in print rather than digitally; and difficulties with viewing images in e-books as compared to experiencing the clear resolution or vibrancy of images in print. Several individuals expressed concern that access to e-books might not be available when they are not able to connect to the Internet, such as when they are in the field conducting research at remote locations. Finally, one individual felt that it is difficult to browse the "electronic stacks" to find e-books, as compared to browsing a physical library shelf.

\section{A PREFERENCE FOR PRINT}

While the majority of focus group participants (15 of 19) indicated that they had used e-books before, a preference for print books was a recurring theme. Several participants commented that they would prefer print books for items that they intend to read cover-to-cover, such as novels. One faculty member noted that while "the younger generation" may prefer e-books, she likes to "curl up on the couch" with print books. Another participant noted that while she would simply adjust if the library increasingly preferred an e-book format when purchasing titles also available in print, she would also be likely to request a print copy from another library (via interlibrary loan or a regional catalog) if the CSU Libraries owned the item only in e-book format.

Respondents also raised concerns about how visuals appear in e-books, with one student noting that while the ability to zoom in on images using a computer or e-reader would be a benefit, he suspected that e-book images would not be as vivid as print images and might be hard to read on certain devices.

Perhaps most interesting were comments from both students and faculty regarding the extent to which their physical bookshelves reflect their identities and facilitate connections with other individuals. As one student noted,

For us, we just have [our] bookshelves and it's a kind of identity to us. [We] are readers, we are people who like to read, and it's part of who we are. If we don't have any books in our house, what does that say about us? I've had so many friends come over and say, "Oh, can I borrow this book?" And if it's on [an e-reader], no one knows what you have read or there's no connection on that level.

Another student commented,

A lot of the stuff I own and have kept have been reference books. I write in my books. I don't fold back pages, but I write in my books, I flag my books. My books and I-if anybody ever wanted to study me after the fact, the books I kept will speak to who I was and what I thought was important. And I've thought about it, clearly, I have thought about the relationship I have with books.

Several respondents indicated that they feel more connected to their reading when they read the item in print. As one graduate student put it,

I'm more invested in my research, I feel, if I'm looking at a book and reading it and have it in my hand, whereas on the computer screen there's something very cold about it. It is easy sometimes to copy and paste, but I've found myself not very invested sometimes. Even with journal articles, I need to print them out, which I know is not the most environmentally friendly thing to do, but I need to print them out because I need to have some sort of physical contact.

Similarly, a faculty member noted that she can't get "continuity of thought" when reading online, versus when reading an item in print. Still another respondent commented on the different intellectual experience of using print versus eresources and commented that "my advisor says all the time, if you want to review an article and be completely analytical, you have to print it."

This perception-that users interact differently with texts in electronic format, in a way that they perceive to be less intellectual and analytical—could be seen as a potential barrier to e-book use in the social sciences.

\section{Use of Books versus Journals}

Through several questions we asked our focus group participants how their use of books and journals may differ: for what purposes and with what frequency did they use both? Generally speaking, faculty and students both reported using both books and journal articles, with select participants indicating that they tend to use one or the other more frequently. Both faculty and student comments clearly indicated that for these social science scholars, books remain important scholarly resources.

Faculty and students readily highlighted using books for specific purposes. For faculty, these purposes included learning or reviewing foundational knowledge; preparing to teach a course or preparing for potential student questions that might arise in an individual class session; framing a research question at the outset of new research and before proceeding to journal literature; and conducting research in a topic area more comprehensively addressed by books than by journal articles. One faculty member indicated that her use of scholarly resources was related primarily to content rather than format. 


\section{FEATURE}

An interesting discussion arose in one faculty focus group regarding departmental reading rooms. These resources, which no longer exist at CSU, contained literature and faculty research that is critical to a given discipline. As one faculty member commented, these collections presented "a knowledge base that was assembled and recommended by the faculty." Several faculty wondered how this might be replicated with e-books and electronic files. As one noted,

When people go into my office, or if I go into someone else's office and I'm talking, I'm browsing their bookshelf. That tells you what they read, and where and what they consider to be knowledge. How do we do that in an e-book format?

There were several comments concerning faculty members' active use of their own office book collections and interest in how these might look in an increasingly electronic environment. One faculty member commented that she houses approximately 1,000 books in her office, keeping within easiest reach those titles that she uses frequently or lends to students and colleagues-many of which are not owned by the university library. Another faculty member commented that he could envision his physical collection someday transforming into a personal collection of electronic resources.

Student responses were more varied, with students reporting the use of anywhere from 10 to 150 books over the past twelve months. Like faculty, students highlighted their use of books for gaining methodological or foundational knowledge, as well as broader theoretical or historical understanding of a topic. One student commented,

First [I use] books, if I don't understand something at a basic level, [to] build a foundation. And then after that, I can go to journals and articles and understand the article.

Another noted, "If I'm trying to get the history on something, a theory, then I tend to go to a book. If I want to read about how it's being applied today, then I might go to a journal article." Several students noted their interest in keeping specific books in print for quick reference and review and continued use over time. Additionally, students commented on using books because they are easier to find than journal articles, for leads (via the references) to journal articles, and as compilations of essays.

Several students provided interesting insight into the process of entering a scholarly community. One noted that he wanted to be "conversant" with both student peers and with older faculty and is therefore familiar with both current and historical literature. Several students described gaining familiarity with specific authors through book and journal literature: "I often read the prefaces just to kind of see what they were doing at the time they wrote this. Why were they so convinced they had to write something on this topic? And then as I read, I feel I know more of the person behind the writing." One student mentioned a professor in their department who requires students to compare several authors' books and perspectives on a common topic.

Student and faculty comments on their use of journal articles were generally unsurprising. Students indicated using journal articles because they are shorter and less time consuming, to access more current research, and because the student's topic seems to be more frequently addressed in journal literature. Several students mentioned that professors frequently require them to use literature published within the last five years unless an older work is seminal. One faculty member noted that if e-books presented more current research, she might prefer them to white papers for current information.

\section{Adapting to Change}

Focus group participants clearly recognized the need to adapt to change and expressed a willingness to do so, with numerous individuals commenting that they see themselves as "transitioning" to e-books: adapting to them and becoming more familiar with them over time. Several respondents mentioned that, as older individuals, e-books present a learning curve for them that may not affect younger students. In several cases, this idea of "rolling with change" was presented hand-in-hand with concern for the loss of print collections. As one respondent noted, "there are some things we'll start to miss out on, and we might not realize what we've lost until it's all in the direction of e-books. But I think we have to move forward with the rest of the world." A faculty member equated the move to e-books to her recent purchase of a smart phone: she didn't really want it, but she realized that she needed one to keep up with her peers and students.

Despite those concerns, most respondents stressed their perception that the Libraries need to move forward with change by purchasing e-books. As one individual noted,

My feeling is that e-books are the future, and so we ought to be working towards that. The more I think about it, e-books offer a lot of advantages for students, in terms of cost and portability and those kinds of things.

This seemed to be a common theme: support for embracing e-books, even though individual faculty and students may not be entirely comfortable with them yet.

\section{Patron-Driven Purchasing}

Focus group participants were generally supportive of the Libraries' experimentation with patron-driven e-book purchasing, and they optimistically imagined that this model might achieve more cost-effective purchasing and improved title access for both simultaneous and distance users. Both students and faculty had insightful comments regarding the 
involvement of librarians in the selection process and, most notably, on the enduring importance of facilitating access to marginal or specialist titles that may be rarely used but are of great significance to select researchers.

Students generally had few negative comments on patrondriven e-book purchasing. They suggested that basing perpetual purchase on use seemed practical. Like faculty, they expressed concern that little-accessed books would not be purchased, while "trendy," high-use titles might be. Interestingly, one student also mentioned their high regard for Colorado's regional catalog, Prospector, which allows memberlibrary users to request items from member institutions. This student indicated that it would be wasteful for patron-driven purchasing efforts to duplicate titles already available from other area libraries.

Faculty made several compelling comments that reflect broader opinions regarding information access: they would encourage patron-driven e-book purchasing if it would facilitate faster and simultaneous user access to more titles. Interestingly, there was little discussion about how e-books might serve distance students. One faculty member noted that successfully requesting print titles from the Libraries presents few problems for students who take the time to learn the request process. There was general agreement that the EBL "rent-to-own" model described to faculty was logical: users could access titles of interest, but perpetual title purchase by the library was not initiated until the short-term loan limit was reached. Like students, faculty expressed concern that seminal or specialist works with a small audience would not be purchased under the patron-driven purchasing model and that, conversely, currently "trendy" titles that do get purchased might have little future use.

Faculty had several comments when queried about the selection role of librarians in the patron-driven purchasing model. These comments included recognition that patrondriven purchasing might decrease librarian workload, but also accompanying concern about possible staffing cuts. Faculty generally suggested that librarians would continue to have an important role in selection, particularly in terms of ensuring access to potentially low-use but significant titles. Interestingly, most focus group participants at some point indicated their familiarity with and active use of interlibrary loan (ILL), yet ILL was not cited as an acceptable alternative to making these marginal and specialist titles locally available.

Lastly, several comments reflected the possibility that patron-driven e-book purchasing might lessen the importance of the library as a physical space and drive changes in library service offerings. One faculty member noted,

It does have implications, too, because you sort of have to re-think the role of the library. If you're not going to physically have books that people are going to be checking out, [then] you have to figure out what other opportunities are there for people to come to the library and use the library.

\section{Purchasing Books Rather Than Obtaining Them from the Library}

Focus group participants were asked about situations where they might choose to purchase books themselves, rather than obtaining them from the library. Their responses provided insight into the role that libraries play in the academic research process, as well as an indication of where library resources do not match users' needs.

Several respondents were not aware that they could ask the library to purchase a particular book that they needed. The majority of respondents indicated that they purchase books they plan to keep as long-term references-critical books that they want to keep on their shelf. As one respondent noted,

For me, the important books probably I'll buy in the future, like the research methods books, statistics books that I may use for my research. But then if I need them in the meantime, I try to scan and keep a few pages that are important.

In particular, respondents identified style guides, research methods texts, statistical resources, "books that provide a theoretical lens," training manuals, and other reference books as the types of resources that they would be likely to purchase outright, rather than borrow them from the library. Many respondents noted that they would be likely to purchase books that they plan to write in. As one respondent stated,

This Kindle is a new thing for me. I'm thinking maybe I've owned mine a year, maybe a little less. I don't like the diagrams in it - the tables, that kind of thing — and I can't write in it. You can highlight text and save it to another program, but it's not the same. And that's one of the reasons I will buy a book instead of borrowing: if I know I want to use it, because I write in my books.

Other reasons why patrons might choose to purchase a book, rather than requesting it from the library, included an immediate need for the title, a need for a more current edition than the library owns, the unavailability of the library's copy, and a need for a title that the patron plans to use frequently.

Conversely, both faculty and students mentioned a number of resources that allow them to request books that they would otherwise need to purchase. Several respondents mentioned requesting titles from a regional library catalog or interlibrary loan. One respondent noted that she uses Amazon.com's "Look inside the book" feature to preview books before purchase. Another stated that she might request a book from the library or interlibrary loan to preview it before purchasing a personal copy.

\section{How Do Students and Faculty Learn About Books?}

Both students and faculty indicated that they discover books 


\section{FEATURE}

of interest from a variety of sources, including bibliographies in articles and books, publisher catalogs, recommendations from peers, publications from professional organizations, and independent searching in library catalogs, Google, or Amazon.com. While one student noted that they now electronically browse the stacks via the library catalog, use of the library catalog for book discovery was less frequently noted than other methods.

Several students described using Amazon.com or Google for initial, broad searches for books (or articles) by a known author or on a specific topic. These comments evidenced a perspective that both sources could quickly and efficiently offer the searcher a big-picture view of available publications, with one student describing Amazon.com as a useful tool "to very quickly distill down what is out there that's available for an author, because they're in the business of selling books." Other features of Amazon.com that students found useful included user reviews, the ability to view pages within books, and a variety of features that facilitate the discovery of related titles. One student noted, "I have to admit that I let Amazon guide me a lot with their recommendations. Because I find some books for class and then it gives me recommendations that people who have bought this have also bought that." Faculty also mentioned identifying books via Google and on Amazon.com.

While both students and faculty commented on receiving book recommendations and leads from peers, student comments suggested that recommendations may be more passively received from peer students and professors-or, in one case, by following Twitter feeds-whereas faculty expressed more proactively and frequently eliciting book recommendations from colleagues while researching and when preparing course instruction. One faculty member noted the easy, collegial manner in which this may occur: "I talk about something, and then the colleague goes over to his shelf and says 'here, look at this book." Faculty also noted that they may know book authors as colleagues and may learn about specific books when attending conference sessions or vendor exhibits. Interestingly, both students and faculty mentioned viewing publisher flyers and catalogs received by their academic departments and learning about books through publications produced by professional organizations. Faculty also mentioned reading book reviews in academic journals, and one student noted the existence of a "faculty publications" bulletin board in their department to highlight new titles.

Students and faculty also described discovering books through searches in the library catalog, library-subscribed databases, and WorldCat; however, comments indicated that this is not the most common method of discovery. Citation chasing was more frequently noted by both groups, with starting points including annotated bibliographies and the bibliographies of articles, books, and textbooks. Students and faculty who had previously used the Libraries' e-books had typically encountered titles accidentally while searching the library catalog; less frequently, they learned about e-books from a librarian, from a Libraries' survey, or on the Libraries' website.

\section{Participant Preferences for Learning About E-books and E-book Use}

To date, the CSU Libraries have done little to publicize the growing e-book collection. During the focus groups the researchers asked participants about how they would like to learn about new e-books and how they would like information about the functions of various e-book platforms.

Participants did not express a preferred communication mechanism for receiving either news of new e-book titles or getting help. They did, however, indicate a desire to receive new e-book title alerts specific to their research interests, for example via a personal profile. Faculty and students were agreeable to receiving alerts via e-mail, RSS feeds, and "e-book of the month" announcements on library or departmental webpages. One student noted that they would be more inclined to pay attention to e-book news routed through the department or their professors, and a faculty member suggested the library might mimic any e-book marketing methods being successfully employed by commercial bookstores.

Both faculty and students recognized the need for accessible, "how-to" information to help users understand e-book functionality (note-taking, printing, and content download options, for example) on different platforms. While no preferred communication mechanism emerged, participant suggestions included online guides; printable tip sheets; brief, online videos; an obvious tab on the Libraries homepage; and drop-in e-book workshops. One faculty member has been impressed by the 24/7 support available through the publisher of an etextbook she uses with a large-enrollment course, and reflected that the Libraries might consider the value of that service model and mimic that publisher's practice of prominently placing the technical support phone number in the e-book interface. Students likewise noted the logic of embedding access to help information directly in an e-book interface.

\section{CONCLUSION}

The themes that emerged from the focus groups conducted at CSU frequently echo the findings of prior e-book use studies, while simultaneously suggesting the need for continued local consideration of user e-book perspectives. The authors anticipate that local studies will be increasingly important as users gain more experience with e-books, e-book interfaces and functionalities evolve, more e-book titles become available, and individual academic libraries refine their deployment of patron-driven purchasing as one element of all monographic purchasing activity.

Because this study population was relatively small and self-selected, these findings may not be readily transferrable to other institutions and may be unique to CSU. Just as ebook use by faculty and students in disciplines beyond the social sciences may differ, so too may e-book use among users at other academic libraries. The replication of studies like this one would be valuable additions to the existing body of research on e-books. 
Existing e-book use studies and our focus group participants' comments clearly indicate that as libraries continue to transition to e-books, users themselves are in transition. In this research study, four of 19 participants indicated that they had not previously used an e-book. While this did not eliminate them from the study, it raises the question of whether results from future research may differ. Over time, as faculty and students gain more experience with e-books, their feedback may also change. Faculty and student perceptions that their intellectual processes may be differently influenced by print and e-texts is one area that offers intriguing potential for further study as users continue to acclimate to e-books.

Also meriting further research are the as-yet unknown influences of patron-driven, e-book purchasing models on users, collections, and the nature of academic libraries themselves. Notably, focus group participants intuitively questioned what effect patron-driven purchasing may have on the Libraries' attention to, and acquisition of, specialty titles-those that are essential to the scholarship of researchers despite their limited audience. Future researchers-and libraries themselves-will need to carefully explore the interaction between users and e-books to ensure that research libraries meet the needs of their constituents, even as a steady shift toward e-books appears inevitable.

\section{ACKNOWLEDGEMENTS}

The authors extend their sincere thanks to the following individuals. For volunteering their time and willingly sharing their perspectives, our focus group participants. For supporting this study, the CSU Libraries Administration. For her early contributions to the design and planning of the study, Teresa Negrucci, previously the CSU Libraries' Collection Assessment and Management Librarian. For her support and her contribution of acquisitions details, Patricia Smith, CSU Libraries' Coordinator of Collections and Contracts. And last but not least, our reviewers.

\section{References and Notes}

1. Apart from the EBL patron-driven purchasing program, librarian selectors may add EBL titles to the collection in lieu of purchasing print or other electronic format firm order titles. These titles need not meet the EBL profile criteria. Additionally, e-format is preferred for select areas of the Libraries' approval plan and these titles may be added to the collection on specifically the EBL platform.

2. Rafael Ball, "E-Books in Practice: The Librarian's Perspective," Learned Publishing 22, no. 1 (2009): 18-22; Lynn Silipigni Connaway and Heather Wicht, "What Happened to the E-Book Revolution? The Gradual Integration of E-Books into Academic Libraries," Journal of Electronic Publishing 10, no. 3 (2007), http:// quod.lib.umich.edu/j/jep/3336451.0010.302?rgn=main;view=ful ltext (accessed Dec. 11, 2011).

3. Connaway and Wicht, "What Happened to the E-Book Revolution?" "Barriers to E-Book Adoption," para. 2.

4. Ball, "E-Books in Practice."

5. Connaway and Wicht, "What Happened to the E-Book Revolution?" "Barriers to E-Books Adoption," para. 6.
6. Ibid., para. 7. The 2011 edition of the Primary Research Group's "Library Use of Ebooks" report presents useful insights into current library practices related to e-books. While the number of libraries sampled is limited, participating libraries report on such issues as current spending on e-books, the acquisition of e-book reading devices, and e-books collection building plans. Primary Research Group, Library Use of Ebooks, 2011 Edition (New York.: Primary Research Group, 2010).

7. Michael Levine-Clark, "Developing a Multiformat Demand-Driven Acquisition Model," Collection Management 35, no. 3/4 (2010): 206.

8. Sarah Thompson, "User-Driven Purchasing: A Pilot Project to Test an Alternative Pricing Model for Springer E-Book Collections," Serials 23, no. 2 (2010): 135.

9. Dracine Hodges, Cyndi Preston, and Marsha J. Hamilton, "PatronInitiated Collection Development: Progress of a Paradigm Shift," Collection Management 35, no. 3/4 (2010): 208-21.

10. Ibid., 219.

11. Edward W. Walton, "From the ACRL 13th National Conference: E-Book Use Versus Users' Perspective," College \& Undergraduate Libraries 14, no. 4 (2007): 25.

12. Wouter van der Velde and Olaf Ernst, "The Future of Ebooks? Will Print Disappear? An End-User Perspective," Library Hi Tech 27, no. 4 (2009): 582.

13. Marc Langston, "The California State University E-Book Pilot Project: Implications for Cooperative Collection Development," Library Collections, Acquisitions \& Technical Services 27, no. 1 (2003): 19-32.

14. Rosie Croft and Corey Davis, "E-Books Revisited: Surveying Student E-Book Usage in a Distributed Learning Academic Library 6 Years Later," Journal of Library Administration 50, no. 5/6 (2010): 563. The 2003 study is reported in Rosie Croft and Shailoo Bedi, "Ebooks for a Distributed Learning University: The Royal Roads University Case," Journal of Library Administration 41, no. 1 (2004): 133-37.

15. Hamid R. Jamali, David Nicholas, and Ian Rowlands, "Scholarly E-Books: The Views of 16,000 Academics Results from the JISC National E-Book Observatory," ASLIB Proceedings 61, no. 1 (2009): 44.

16. Cynthia L. Gregory, "But I Want a Real Book: An Investigation of Undergraduates' Usage and Attitudes toward Electronic Books," Reference \& User Services Quarterly 47, no. 3 (2008): 270.

17. Heting Chu, "Electronic Books: Viewpoints from Users and Potential Users," Library Hi Tech 21, no. 3 (2003): 340-46; Michael Levine-Clark, "Electronic Book Usage: A Survey at the University of Denver," portal: Libraries \& the Academy 6, no. 3 (2006): 28599; Peter Hernon, Rosita Hopper, and Michael R. Leach, "E-Book Use by Students: Undergraduates in Economics, Literature, and Nursing," Journal of Academic Librarianship 33, no. 1 (2007): 3-13; Ian Rowlands et al., "What Do Faculty and Students Really Think About E-Books?" ASLIB Proceedings 59, no. 6 (2007): 489-511; Allen W. McKiel, "2007 Global Faculty E-Book Survey," www.ebrary.com/corp/collateral/en/Survey/ebrary_faculty_survey 2007.pdf (accessed Dec. 11, 2011); Allen W. McKiel, "2008 Global Student E-Book Survey," www.ebrary.com/corp/collateral/ en/Survey/ebrary_student_survey_2008.pdf (accessed Dec. 11, 2011); Jamali, Nicholas, and Rowlands, "Scholarly E-Books"; Rajiv Nariani, "E-Books in the Sciences: If We Buy It Will They Use It?" Issues in Science \& Technology Librarianship no. 59 (2009), www.istl.org/09-fall/article3.html (accessed Dec. 11, 2011); Croft and Davis, "E-Books Revisited." The authors consulted the 2007 and 2008 ebrary e-book surveys because of their frequent mention in the e-book literature, despite the fact that the surveys were self-published by ebrary and nonscholarly in nature; the results of those surveys echo results from academic research on e-books.

18. Croft and Davis, "E-Books Revisited," 559.

19. Hernon, Hopper, and Leach, "E-Book Use by Students"; Jamali, Nicholas, and Rowlands, "Scholarly E-Books"; Levine-Clark, 


\section{FEATURE}

"Electronic Book Usage"; Primary Research Group, Library Use of Ebooks, 2011 Edition; Gregory, "But I Want a Real Book"; Primary Research Group, The Survey of American College Students: Student Use of Library E-Book Collections (New York: Primary Research Group, 2009).

20. Jamali, Nicholas, and Rowlands, "Scholarly E-Books," 36.

21. Hernon, Hopper, and Leach, "E-Book Use by Students"; Jamali, Nicholas, and Rowlands, "Scholarly E-Books."

22. Hernon, Hopper, and Leach, "E-Book Use by Students."

23. Ibid.

24. Ibid; Jamali, Nicholas, and Rowlands, "Scholarly E-Books."

25. Croft and Davis, "E-Books Revisited"; Jamali, Nicholas, and Rowlands, "Scholarly E-Books"; Levine-Clark, "Electronic Book Usage."

26. Jamali, Nicholas, and Rowlands, "Scholarly E-Books," 37.

27. Croft and Davis, "E-Books Revisited."

28. Gregory, "But I Want a Real Book"; Jamali, Nicholas, and Rowlands, "Scholarly E-Books"; Levine-Clark, "Electronic Book Usage."

29. Gregory, "But I Want a Real Book," 270.

30. Levine-Clark, "Electronic Book Usage," 294.

31. Jamali, Nicholas, and Rowlands, "Scholarly E-Books."

32. Ibid.

33. Gregory, "But I Want a Real Book"; Levine-Clark, "Electronic Book Usage."

34. Levine-Clark, "Electronic Book Usage," 292.

35. Croft and Davis, "E-Books Revisited"; Jamali, Nicholas, and Rowlands, "Scholarly E-Books."

36. Croft and Davis, "E-Books Revisited," 559.

37. Hernon, Hopper, and Leach, "E-Book Use by Students"; LevineClark, "Electronic Book Usage"; David Nicholas et al., "UK Scholarly E-Book Usage: A Landmark Survey," ASLIB Proceedings 60, no. 4 (2008): 311-34.

38. Hernon, Hopper, and Leach, "E-Book Use by Students," 8.

39. Levine-Clark, "Electronic Book Usage," 292.
40. Nicholas et al., "UK Scholarly E-Book Usage," 322

41. Gregory, "But I Want a Real Book," 270.

42. A. Noorhidawati and Forbes Gibb, "How Students Use E-BooksReading or Referring?" Malaysian Journal of Library \& Information Science 13, no. 2 (2008): 6.

43. Rowlands et al., "What Do Faculty and Students Really Think About E-Books?" 510.

44. K. T. Anuradha and H. S. Usha, "E-Books Access Models: An Analytical Comparative Study," Electronic Library 24, no. 5 (2006): 662-79.

45. Ibid.

46. James Bierman, Lina Ortega, and Karen Rupp-Serrano, "E-Book Usage in Pure and Applied Sciences," Science \& Technology Libraries 29, no. 1/2 (2010): 79.

47. Ibid., 82 .

48. Jody Bales Foote and Karen Rupp-Serrano, "Exploring E-Book Usage among Faculty and Graduate Students in the Geosciences: Results of a Small Survey and Focus Group Approach," Science E Technology Libraries 29, no. 3 (2010): 216-34.

49. Ibid., 228.

50. Ibid., 223

51. Nariani, "E-Books in the Sciences."

52. Michael Levine-Clark, "Electronic Books and the Humanities: A Survey at the University of Denver," Collection Building 26, no. 1 (2007): 7-14.

53. Ibid., 8

54. David Nicholas, Ian Rowlands, and Hamid R. Jamali, "E-Textbook Use, Information Seeking Behaviour and Its Impact: Case Study Business and Management," Journal of Information Science 36, no. 2 (2010): 263-80.

55. Ibid., 278.

56. Richard A. Krueger and Mary Anne Casey, "Analyzing Focus Group Results," in Focus Groups: A Practical Guide for Applied Research (Los Angeles: Sage, 2009).

\section{APPENDIX. FOCUS GROUP QUESTIONS}

1. By a show of hands, how many of you have ever used-that is to say, read-an e-book, in part or whole?

2. Prior to receiving the invitation to participate in this focus group, how many of you were aware that our library provides access to e-books?

3. If you can recall, how and when did you learn that our library provides access to e-books?

4. Tell me how you use books_-print or e-books—in your [research/research and teaching] and whether you tend to use books more or less than other resources such as journal articles.

5. Tell me about all the ways in which you may identify or learn about print or e-books to use in your [research/research and teaching].

6. Tell me about occasions when you may choose to buy books for your [research/research and teaching] with your own funds or with research grant funds, rather than borrowing them from a library.

7. Have you personally used e-books in your research and if so, could you describe your experiences with them?

8. Under what circumstances would you prefer to use an e-book rather than a print book? If you haven't used e-books, we're still interested in your thoughts on why and when you might prefer one over the other.

9. If a book is available in both e-book and print formats, the library may increasingly choose to purchase the e-book rather than the print. What are your thoughts on this and how, if at all, might this influence your use of library collections?

10. The library is experimenting with a new purchasing model for e-books called patron-driven purchasing. When a user accesses an e-book through the library website, it is on a pay-per-view basis. After several uses, the library purchases the book for perpetuity. So, rather than librarians deciding what to purchase, use determines whether an e-book is purchased. What do you think of this approach to determining which e-books to purchase for the library's collection?

11. What, if anything, could the library do to inform you about available e-books and make it easy for you to use them?

12. Do you have any final comments to share? 